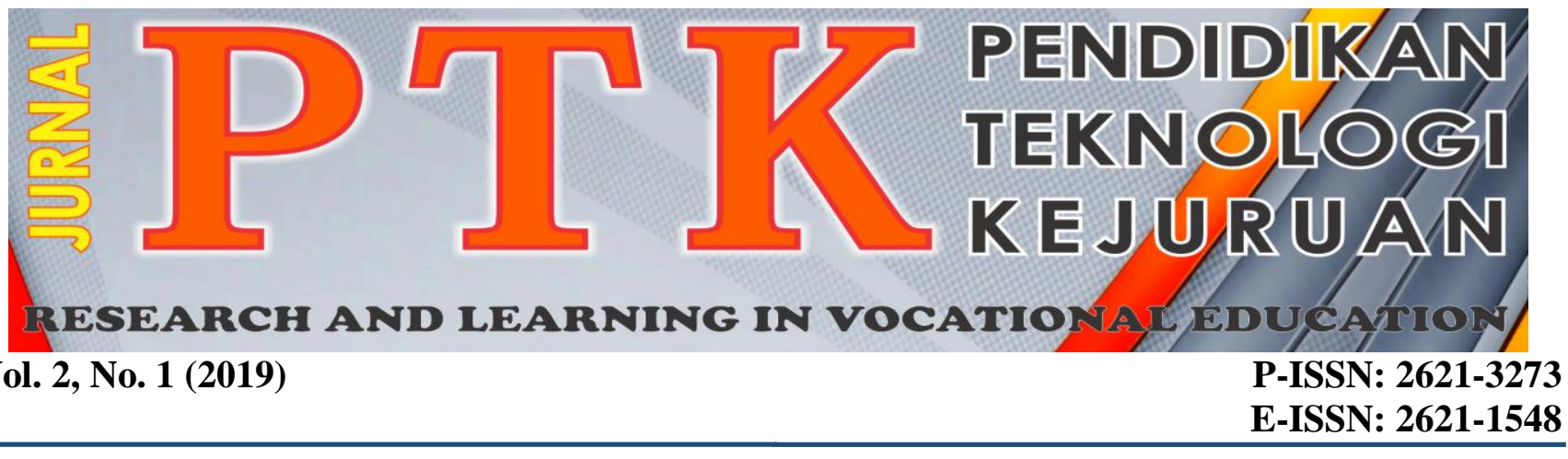

\title{
Analisis Pelatihan Penggunaan Media Pembelajaran CD Interaktif Berbasis Multimedia Dan Modul IPA SD Kelas III di Kecamatan Koto Tangah Kota Padang
}

\author{
Nelda Azhar ${ }^{1}$, Kasman Rukun $^{2}$, Asrul Huda $^{3}$ \\ ${ }^{123}$ Program Studi Pendidikan Teknik Informatika, Fakultas Teknik Universitas Negeri Padang \\ "Corresponding author, e-mail: neldaazhar@yahoo.co.id ${ }^{1}$
}

\begin{abstract}
Abstrak - Guru dan juga dunia pendidikan pada umumnya diharapkan mampu menciptakan sumber daya manusia yang berkualitas baik secara keilmuan maupun secara sikap mental yang positif. Untuk itu, dalam proses pembelajaraan, metode, strategi atau kegiatan pembelajaran yang dilakukan oleh guru seyogyanya adalah sesuatu yang benar-benar tepat dan bermakna, untuk memperoleh hasil yang maksimal sesuai dengan tahap perkembangan anak, maka strategi yang guru gunakan dalam menyampaikan sesuatu, baik yang berupa penanaman sikap, mental, perilaku, kepribadian maupun kecerdasan harus tepat sasaran, tujuh kecerdasan proporsional. Dalam kehidupan kita tidak dapat memungkiri bahwa yang turut menentukan sikap, mental, perilaku, kepribadian dan kecerdasan anak adalah pendidikan, pengalaman dan latihan-latihan yang diberikan serta dialami peserta didik sejak mereka kecil. Hasil survey awal menunjukan pada beberapa sekolah yang tergabung dalam Kelompok Kerja Guru (KKG) Gugus V untuk pembelajaran IPA SD Kelas III belum menunjukan pembelajaran yang optimal. Hasil survey awal menunjukan bahwa kelompok kerja guru (KKG) yang tergabung pada wilayah IV gugus V Kecamatan Koto Tangah yang berjumlah 11 sekolah sering mengalami permasalahan proses pembelajaran disekolah yang belum terlaksana secara optimal karena kekurangan media pembelajaran dan alat peraga pembelajaran IPA. Kegiatan ceramah yang dilakukan oleh guru sama sekali tidak salah, namun ketika ceramah, interaksi guru dengan siswa kurang begitu berjalan, guru hanya cenderung ceramah dan tidak memperhatikan situasi dan kondisi siswa di kelas. Metode ceramah juga tidak bisa dilepaskan dari proses pembelajaran. Metode ceramah akan membuat siswa mendapat hasil belajar yang maksimal jika dikemas dengan lebih baik dan menarik.
\end{abstract}

Kata kunci: Media Pembelajaran; Multimedia

Abstract-Teachers and the world of education are generally expected to be able to create quality human resources both scientifically and positively. For this reason, in the learning process, the methods, strategies or learning activities carried out by the teacher should be something that is truly appropriate and meaningful, to obtain maximum results according to the stage of development of the child, then the strategies that the teacher uses in conveying something, both in the form of planting attitudes, mentality, behavior, personality and intelligence must be on target, seven proportional intelligence. In our lives we cannot deny that the ones who determine the attitudes, mentality, behavior, personality and intelligence of children are education, experience and exercises given and experienced by students since they were small. The results of the preliminary survey showed that several schools belonging to the Teacher Working Group (KKG) of Cluster V for science learning in SD III had not shown optimal learning. The results of the initial survey showed that the teacher working group (KKG) incorporated in the IV cluster V region of Koto Tangah Subdistrict, amounting to 11 schools, often experienced problems in the school learning process that had not been carried out optimally due to lack of learning media and science learning aids. The lecture activities carried out by the teacher were not wrong at all, but when lecturing, the teacher's interaction with students was not very running, the teacher only tended to lecture and did not pay attention to the situation and condition of students in the class. The lecture method also cannot be separated from the learning process. The lecture method will make students get maximum learning outcomes if packaged better and interestingly.

Keywords : learning media, multimedia 


\section{Pendahuluan}

Perkembangan dunia pendidikan pada saat ini tidak di pungkiri telah memasuki era baru, yaitu era ekonomi global, serta era ilmu pengetahuan dan informasi di berbagai bidang. Pendidikan sekarang tidak lagi dimaksudkan untuk sekedar mendapatkan pengetahuan, tetapi lebih diarahkan agar anak didik memiliki keterampilan tertentu agar dapat bersaing dengan lingkungannya. Bentuk pendidikan yang berjenis pendidikan kejuruan bertujuan untuk mempersiapkan peserta didiknya mampu dalam bidang tertentu sesuai dengan kebutuhan industri maupun masyarakat umum.

Suatu kegiatan pembelajaran akan sangat bermakna bagi peserta didik, apabila kegiatan pembelajaran tersebut mengutamakan interaksi dan komunikasi yang baik antara guru dan peserta didiknya, artinya kegiatan pembelajaran yang dilakukan merupakan tempat bagi peserta didik dalam mengembangkan potensi yang ada dalam dirinya, sehingga tujuan pendidikan yang ingin dicapai dapat terlaksana. Usia 6-8 tahun otak anak masih dalam tahap perkembangan atau mengalami masa kematangan. Pada usia delapan tahun normalnya anak berada pada jenjang kelas dua atau tiga SD yang sebenarnya masih merupakan masamasa keemasan bagi anak, karena proses menerima dan menyerap berbagai bentuk pengalaman baik dari guru ataupun lingkungan sekitar akan dengan mudah mereka terima. Salah satu komponen yang sangat penting dalam dunia pendidikan adalah guru, guru merupakan ujung tombak pendidikan. Dalam konteks ini, guru mempunyai peranan yang sangat besar dan strategis, karena gurulah yang berada di barisan paling depan dalam pelaksanaan pendidikan. Guru langsung berhadapan dengan peserta didik dalam kegiatan pembelajaran yang di dalamnya mencakup kegiatan pentransferan ilmu pengetahuan dan teknologi serta penanaman nilai-nilai positif melalui bimbingan dan juga tauladan.

Maka dari itu diperlukan persiapan berbentuk pemberian pelajaran yang bersifat pelatihan keterampilan selain pelajaran bersifat adapatif maupun normatif agar menjadi peserta didik yang kompeten secara keilmuan maupun secara akhlak setelah lulus.

Bentuk pemberian pelajaran yang banyak diterapkan pada dunia pendidikan adalah metode konvensional. Jadi banyak terjadi kecendrungan hasil dari pembelajaran tersebut tidak dapat tepat guna.Untuk mengatasi hal tersebut, para praktisi serta para ahli pendidikan terus menerus mengembangkan metodepenyajian dalam proses pembelajaran.
Menurut perjalanan sejarah dunia pendidikan telah mengalami empat tahap perubahan ditinjau dan cara penyajian materi pelajarannya. Perkembangan pertama tatkala dalam masyarakat tumbuh suatu profesi baru yang disebut "guru"yang diberi tanggung jawab untuk melaksanakan pendidikan.Perkembangan kedua dimulai dengan digunakan bahasa tulisan disamping bahasa lisan dalam penyajian pelajaran. Perkembangan ketiga terjadi dengan ditemukan teknik pencetakan yang memungkinkan diperbanyak bahan bacaan dalam bentuk teks perkembangan pendidik yang keempat terjadi dengan mulai masuknya teknologi berikut produknya yang menghasilkan alat mekanis, optis, maupun elektronis.

Guru dan juga dunia pendidikan pada umumnya diharapkan mampu menciptakan sumber daya manusia yang berkualitas baik secara keilmuan maupun secara sikap mental yang positif. Untuk itu, dalam proses pembelajaraan, metode, strategi atau kegiatan pembelajaran yang dilakukan oleh guru seyogyanya adalah sesuatu yang benar-benar tepat dan bermakna, untuk memperoleh hasil yang maksimal sesuai dengan tahap perkembangan anak, maka strategi yang guru gunakan dalam menyampaikan sesuatu, baik yang berupa penanaman sikap, mental, perilaku, kepribadian maupun kecerdasan harus tepat sasaran, tujuh kecerdasan proporsional. Yang sangat kita khawatirkan dan harus dihindari adalah jangan sampai masa-masa keemasan anak tersebut malah terbalik, justru menjadi masa-masa penumpulan otak anak hanya karena strategi, teknik, metode atau model pembelajaran yang guru sampaikan tidak tepat dan tidak sesuai dengan masa perkembangan anak.

Kompenen pendukung lain selain manusia pada sistem pembelajaran sekarang ini menjadi terasa peran pentingnya ,karenadunia pendidikan sudah tidak lagi berkonotasi pada memperoleh pengetahuan berasal dari satu sumber,yaitu sekolah yang proses informasinya hanya diperoleh dari guru sebagai orang yang berilmu. Proses pendidikan sekarang telah mulai berupaya mengarahkan kemampuan siswa untuk aktif mencari informasi dan pengetahuan melalui berbagai macam sumber.

Sumber belajar adalah segala sesuatu yang dapat digunakan oleh manusia untuk belajar sumbersumber belajarini diindentifikasikan sebagai pesan, orang, bahasa, peralatan, teknik, dan latar atau lingkungannya. Kronologi dan teknis bagaimana pengetahuan disebarkan dari satu sumber kesumberlainnya terdiri beberapa pola seperti utamanya,dahulu,informasi didapat dari mulut kemulut, kemudian berkembang dengan munculnya 
media cetak.lalu semakin berkembang dengan ditemukannya media audio visual sekarang sering dengan perkembangan zaman ribuan bahkan jutaan informasi dapat diperoleh hanya dengan menekan tombol-tombol komputer pada era ketika orang sangat mengandalkan komputer komputer sebagai salah satu sumber dalam mencari informasi termasuk dalam bidang pendidikan.

Media pembelajaran setiap tahun selalu mengalami perkembangan, karena masing-masing media itu mempunyai kelemahan, berdasarkan penggunaannya perlu diadakan penemuan media baru dan pemanfaatan media yang telah diperbaharui. Karena peserta didik cepat merasakan kebosanan, saat menerima pelajaran, sebab dengan media yang kurang menarik akan bersifat verbalistik, maka diadakannya perbaikan media guna menunjang proses belajar mengajar. Untuk mencapai tujuan kurikulum pembelajaran pada proses belajar mengajar maka perlu didukung media dan bahan ajar yang baik yaitu bahan ajar yang mampu menarik minat siswa, sesuai dengan zaman dan tidak menyimpang dari kurikulum.

Media pembelajaran merupakan alat dan bahan yang digunakan untuk keperluan pembelajaran dalam upaya meningkatkan hasil belajar [3]. Ada berbagai macam jenis media pembelajaran, diantaranya media visual, audio, dan multimedia [2]. Multimedia merupakan media yang memanfaatkan media komputer yang mampu menggabungkan beberapa media lain seperti audio dan visual dalam penyajiannya. Multimedia merupakan kombinasi dari teks, grafik, suara, animasi, dan video yang disampaikan melalui komputer atau media elektronik lainnya [5]. Pendapat lain mengenai multimedia diungkapkan oleh Mayer (2009: 4), mengungkapkan bahwa multimedia merujuk pada teknologi untuk menyajikan materi dalam bentuk verbal dan visual.

Dalam dunia pendidikan sendiri komputer digolongkan kedalam salah satu sumber atau media (AECT 1994) Media merupakan alat untuk menyampaikan pesan atau menghantarkan pesan dari pengirim kepada penerima pesan penggunaan media dalam pembelajaran sangat penting karena dapat membantu menyampaikan informasi dengan lebih mudah dan jelas.Sehingga dapat memperlancar dan meningkatkan proses dan hasil belajar.Kehadiran media dalam pembelajaran juga dapat memberikan pengalaman yang menyenangkan serta tidak membosankan bagi siswa.

Hampir dipastikan bahwa dalam setiap pembelajaran pasti menggunakan media. Penggunaan media tidak hanya akan menyenangkan bagi siswa,tapi juga sangat membantu guru dalam menyampaikan materi pelajaran. Dengan penggunaan media siswa akan termetovasi untuk belajar kini telah banyak program komputer yang bertujuan untuk membantu guru dan siswa dalam proses pembelajaran. Salah satunya yang kita kenal dan mulai menjadi tren dalam dunia pendidikan saat ini adalah CAI (Computer Assisted Instruction). Atau dalam bahasa Indonesia yang baku dan lazim disebut dengan penbelajaran Berbantuan Komputer atau disingkat dengan PBK.

Kegiatan ceramah yang dilakukan oleh guru sama sekali tidak salah, namun ketika ceramah, interaksi guru dengan siswa kurang begitu berjalan, guru hanya cenderung ceramah dan tidak memperhatikan situasi dan kondisi siswa di kelas. Metode ceramah juga tidak bisa dilepaskan dari proses pembelajaran. Metode ceramah akan membuat siswa mendapat hasil belajar yang maksimal jika dikemas dengan lebih baik dan menarik.

Tercapainya tujuan pembelajaran pada mata pelajaran dasar kompetensi kejuruan tidak lepas dari peran utama seorang guru. Seorang guru tidak hanya dituntut sekedar menyampaikan ilmu, tetapi juga harus dapat menciptakan suasana pembelajaran yang kondusif sehingga proses pembelajaran dapat belangsung secara aktif. Berdasarkan pertimbangan tersebut, maka diperlukan metode pembelajaran yang mampu melibatkan peran serta siswa secara menyeluruh sehingga kekuatan belajar mengajar tidak hanya didominasi oleh siswa-siswa tertentu saja. Pemilihan metode pembelajaran tersebut di harapkan dapat meningkatkan peran serta dan keaktifan siswa dalam mempelajari dan menelaah ilmu.

Hasil survey awal menunjukan bahwa kelompok kerja guru (KKG) yang tergabung pada wilayah IV gugus V Kecamatan Koto Tangah yang berjumlah 11 sekolah sering mengalami permasalahan proses pembelajaran disekolah yang belum terlaksana secara optimal karena kekurangan media pembelajaran dan alat peraga pembelajaran IPA.

\section{Studi PUStaka}

\section{A. Konsep Belajar dan Pelatihan}

Belajar merupakan kebutuhan setiap orang, hampir setiap orang, setiap kecakapan, pengetahuan, ketrampilan, kebiasaan, kegemaran dan sikap manusia terbentuk, dimodifikasi berkembang karena belajar. Sehubungan dengan pengertian belajar, Gagne berpendapat bahwa aktifitas pribadi yang menghasilkan perubahan dalam penampilan kemampuan, yang bersifat relatif tetap. Berikut Kemp mengemukakan, belajar adalah merupakan aktifitas pengetahuan atau keterampilan yang dilakukan oleh pelajar dan sepenuhnya pada pelajar itu sendiri. 
Secara umum Herman mengatakan, latihan keterampilan dapat didefinisikan sebagai suatu cara sistematik yang diberikan kepada seseorang untuk mendapatkan suatu keterampilan tertentu. Ahli lain Wekley dan Yuke lebih terinci mengemukakan bahwa latihan dan pengembangan keterampilan adalah istilah-istilah yang menyangkut usaha-usaha berencana yang diselenggarakan agar tercapainya penuasaan keterampilan bertujuan untuk menyiapkan peserta kepada suatu pekerjaan tertentu yang berguna bagi kehidupannya.

Penguasaan belajar keterampilan tersebut mencakup tiga unsur yaitu, pengetahuan, sikap dan keterampilannya itu sendiri yang diperlukan dalam pembekalan menghadapi suatu pekerjaan. Lebih jauh dikemukakan oleh D. Budianto bahwa latihan keterampilan adalah bagian dari pendidikan yang dikategorikan dalam pendidikan informal dan merupakan proses untuk memperoleh atau meningkatkan pengetahuan untuk memenuhi persyaratan suatu pekerjaan yang berlangsung diluar sistem pendidikan formal dalam waktu relatif singat dan dengan mengutamakan praktek daripada teori.

Seiring dengan perkembangan teknologi di bidang komputer saat ini, baik dalam perangkat keras (hardware) maupun perangkat lunak (software), hampir sebagian besar pekerjaan manusia kini diselesaikan dengan bantuan komputer. Dengan demikian, komputer dapat dikatakan sebagai salah satu alat bantu manusia dalam menyelesaikan suatu pekerjaan. Pemakaian komputer sering digunakan untuk hal-hal yang berkenaan dengan pemrosesan data (data processing) dan pengolahan kata (word processing). Salah satu alasan, mengapa komputer cenderung digunakan sebagai alat bantu dalam menyelesaikan suatu pekerjaan karena pekerjaan yang dilakukan menggunakan komputer memiliki kecepatan proses yang lebih dapat diandalkan.

\section{B. Hakekat Pendidikan Kecakapan dalam Pendidikan Non Formal}

Hakekat pendidikan kecakapan hidup adalah upaya untuk meningkatkan keterampilan, pengetahuan, sikap dan kemampuan yang memungkinkan warga belajar untuk dapat hidup mandiri. Secara profesional, maka pendidikan kecakapan hidup adalah kecakapan yang dimiliki oleh seseorang untuk berani menghadapi problema hidup dan kehidupan dengan wajar tanpa merasa tertekan, kemudian secara proaktif dan kreatif mencari serta menemukan solusi sehingga akhirnya mampu mengatasinya.

Secara operasional, program life skill dalam pendidikan non formal pada hakikatnya dimaksudkan untuk mengembangkan 4 (empat) jenis kecakapan. Keempat jenis dimaksud meliputi:

(1) Kecakapan pribadi, mengenal diri sendiri, berfikir rasional dan percaya diri;

(2) Kecakapan sosial, melakukan kerjasama, bertenggang rasa, dan memiliki tanggung jawab sosial;

(3) Kecakapan akademik, berfikir secara ilmiah dan kritis, melakukan penelitian dan percobaan dengan menggunakan pendekatan ilmiah;

(4) Kecakapan vokasional, kecakapan yang berhubungan dengan pekerjaan tertentu yang terdapat di dalam masyarakat (seperti bidang jasa, perbengkelan, jahit menjahit), dan produksi barang tertentu (peternakan, pertanian, perkebunan, dan sebagainya).

Keempat jenis kecakapan tersebut di ata, harus dilandasi kecakapan spiritual, yakni keimanan, ketaqwaan, moral, budi pekerti luhur. Jika hak terakhir ini diabaikan, maka kecakapan (skill) yang dimiliki seseorang bisa menjeruskannya ke berbagai tindakan yang mengingkari kehendak ilahi.

\section{Prinsip Latihan Keterampilan}

Kegiatan pelatihan keterampilan yang dilkuakan terhadap kelompok sasaran, tentu diharapkan bisa diraih hasil yang maksimal. Dalam perancangan pembelajaran untuk suatu latihan keterampilan Gagul (1968), mengemukakan tiga prinsip pokok yang tidak bisa diabaikan, yakni:

(1)Penentuan jenis tugas-tugas yang harus dilakukan secara bersama dengan peserta agar dapat memberikan keterampilan sesuai dengan apa yang diharapkan darinya;

(2) Keyakinan bahwa tugas-tugas yang diberikan tersebut dapat diselesaikan oleh peserta;

(3) Pengaturan situasi belajar sedemikian rupa, sehingga melalui kegiatan itu akan diperoleh efek optimal dari komponen-komponen yang ada di dalam latihan keterampilan tersebut.

Mempertimbangkan prinsip-prinsip di atas, maka strategi pembelajaran pada latihan keterampilan dasar-dasar komputer ini adalah dengan: mengembangkan pengetahuan; memberikan informasi penting; menjelaskan karakteristik pekerjaan dengan tepat; menyusun prosedur dan langkah kerja secara sistematis; serta merancang alat bantu pembelajaran. Kesemuanya itu dimaksudkan agar kelompok sasaran/ peserta latihan keterampilan dapat menyelesaikan pekerjaan secara memuaskan sesuai dengan tujuan yang diharapkan.

Pelaksanaan latihan keterampilan harus secara sistematis dan dalam jangka waktu yang singkat, karena dengan latihan keterampilan diharapkan dengan segera dapat terjun kedunia kerja. Sehubungan dengan itu, Butler mengatakan: 
idealnya latihan keterampilan harus diadakan di tempat yang memiliki sifat-sifat karakteristik pekerjaan yang akan datang, karena keterampilan, pengetahuan, kebiasaan kerja serta sikap hanya akan dapat dipelajari dan dikembangkan dengan baik di dalam lingkungan yang menggambarkan pekerjaan peserta di dunia nyata. Namun untuk kegiatan pelatihan ini, hal itu tidak mungkin dilaksanakan, terutama karena karakter kelompok sasaran amat berbeda, dan mereka itu belum dipersiapkan untuk langsung terjun kedua kerja. Lagi pula pelatihan ini dilakukan oleh para akademisi, bukan oleh perusahaan yang menyiapkan teknisi untuk divisi tertentu.

Teknologi informasi merupakan suatu bidang yang menangani pengolahan data menjadi suatu informasi yang dapat dimanfaatkan agar ia siapuntuk disajikan, seperti informasi umum (public information) dan informasi lokal (local information). Sebagai contoh informasi umum, seperti penggunaan internet, untuk melihat dan mengambil informasi seperti berita, cuaca dan sebagainya. Lokal informasi, seperti jaringan lokal di dalam perusahaan yang berfungsi untuk menyimpan dan mengirim informasi yang sifatnya rahasia dan hanya diberikan kepada pihak kompeten dan/ atau yang membutuhkan saja. Artinya, ia bukan untuk konsumsi publik yang dapat diakses atau diketahui oleh siapa pun.

\section{Pengertian Media Pembelajaran}

Kata mediaberasal dari bahasa Latin merupakan bentuk jamak dari kata medium, yang secara marfiah berarti perantara atau pengantar.Dengan demikian, media merupakan wahana penyalur informasi belajar atau penyalur pesan.

Heinich, dkk dalam Azhar mengemukakan "istilah medium sebagai perantara yang mengantar informasi antara sumber dengan penerima". Jadi, televisi, film, foto, radio, rekaman audio, gambar yang diproyeksikan, bahan-bahan cetakan, dan sejenisnya adalah media komunikasi. Apabila media itu membawa pesan-pesan atau informasi yang bertujuan instruksional atau mengandung maksudmaksud pengajaran maka media itu disebut media pembelajaran.

Media pembelajaran adalah teknologi pembawa pesan yang dapat dimanfaatkan untuk keperluan pembelajaran, antara lain: film, video, LCD, televisi, dan slide proyektor. Sebenarnya media pembelajaran tidak hanya terbatas pada media elektronik melainkan segala sesuatu yang digunakan untuk memperlancar proses belajar mengajar yang mempunyai tujuan agar materi yang diajarkan lebih mudah dipahami oleh peserta termasuk papan tulis, penggaris, buku, maupun peraga manual. Sehingga perbedaan alat peraga dan media, terletak pada fungsinya bukan pada subtansinya. Suatu sumber belajar disebut alat peraga jika hanya berfungsi sebagai alat bantu pembelajaran. Sedangkan sumber belajar disebut media jika merupakan bagian integral dari seluruh proses pembelajaran.

Media memiliki peran yang sangat penting dalam kegiatan pembelajaran. Media berfungsi menjembatani antara guru dan siswa dalam rangka menyampaikan materi bahan ajar, membantu siswa memahami bahan ajar dan memfasilitasi siswa melakukan kegiatan pembelajaran. Dan akhirnya media pembelajaran dapat mengatasi keterbatasan indra, ruang dan waktu, serta dapat memberikan kesamaan pengalaman kepada siswa tentang peristiwa-peristiwa di lingkungan mereka.

Heinich menjabarkan media pembelajaran dalam bukunya meliputi :

1. Media yang tidak diproyeksikan (non projected media), contohnya: realita, model, bahan grafis (graphical material), display.

2. Media yang di proyeksikan (projected media), contohnya: OHT, Slide, Opaque.

3. Media audio (audio) kaset, contohnya: vision, active audio vision.

4. Media video (video).

5. Media berbasis komputer (computer based media), contohnya: Computer Assisted Instruction (CAI).

Sudjana \& Rivai mengemukakan manfaat media pembelajaran dalam proses belajar siswa, yaitu:

1. Pembelajaran akan lebih menarik perhatian siswa sehingga dapat menumbuhkan motivasi belajar;

2. Bahan pembelajaran akan lebih jelas maknanya sehingga dapat lebih dipahami oleh siswa dan memungkinkannya menguasai dan mencapai tujuan pembelajaran

3. Metode mengajar akan lebih bervariasi, tidak semata-mata komunikasi verbal melalui penuturan kata-kata oleh guru, sehingga siswa tidak bosan dan guru tidak kehabisan tenaga, apalagi kalau guru mengajar pada setiap jam pelajaran.

4. Siswa dapat lebih banyak melakukan kegiatan belajar sebab tidak hanya mendengarkan uraian guru, tetapi juga aktivitas lain seperti mengamati, melakukan, mendemonstrasikan, memerankan, dan lain-lain.

Encyclopedia of Educational Research dalam Azhar merincikan manfaat media pendidikan sebagai berikut :

1. Meletakkan dasar-dasar yang konkret untuk berpikir, oleh karena itu mengurangi verbalisme.

2. Memperbesar perhatian siswa. 
3. Meletakkan dasar-dasar yang penting untuk perkembangan belajar, oleh karena itu membuat pelajaran lebih mantap.

4. Memberikan pengalaman nyata yang dapat menumbuhkan kegiatan berusaha sendiri di kalangan siswa

5. Menumbuhkan pemikiran yang teratur dan kontinyu, terutama melalui gambar hidup.

6. Membantu tumbuhnya pengertian yang dapat membantu perkembangan kemampuan berbahasa.

7. Memberikan pengalaman yang tidak mudah diperoleh dengan cara lain, dan membantu efisiensi dan keragaman yang lebih banyak dalam belajar.

Bedasarkan uraian dan pendapat beberapa ahli di atas, dapat disimpulkan beberapa manfaat dari penggunaan media pembelajaran di dalam proses belajar mengajar sebagai berikut :

1. Media pembelajaran dapat memperjelas penyajian pesan dan informasi sehingga dapat memperlancar dan meningkatkan proses dan hasil belajar.

2. Media pembelajaran dapat meningkatkan dan mengarahkan perhatian anak sehingga dapat menimbulkan motivasi belajar, interaksi yang lebih langsung antara siswa dan lingkungannya, dan kemungkinan siswa untuk belajar sendirisendiri sesuai dengan kemampuan dan minatnya.

3. Media pembelajaran dapat mengatasi keterbatasan indera, ruang, dan waktu;

a. Objek atau benda yang terlalu besar di tampilkan langsung di ruang kelas dapat diganti dengan gambar, foto, slide, realita, film, radio, atau model.

b. Objek atau benda yang terlalu kecil yang tidak tampak oleh indera dapat disajikan dengan bantuan mikroskop, film, slide, atau gambar.

c. Kejadian langka yang terjadi di masa lalu atau terjadi sekali dalam puluhan tahun dapat ditampilkan melalui rekaman video, film, foto, slide disamping secara verbal.

d. Objek atau proses yang amat rumit seperti peredaran darah dapat ditampilkan secara kongkret melalui film, gambar, slide, atau simulasi komputer.

e. Kejadian atau percobaan yang dapat membahayakan dapat disimulasikan dengan media seperti komputer, film, dan video.

f. Peristiwa alam seperti terjadinya letusan gunung berapi atau proses yang dalam kenyataan memakan waktu lama seperti proses kepompong menjadi kupu-kupu dapat disajikan dengan teknik-teknik rekaman seperti time-lapse untuk film, video, slide, atau simulasi komputer.

g. Media pembelajaran dapat memberikan kesamaan pengalaman kepada siswa tentang peristiwa-peristiwa di lingkungan mereka, serta memungkinkan terjadinya interaksi langsung dengan guru, masyarakat, dan lingkungannya misalnya melalui karyawisata, kunjungan-kunjungan ke museum atau kebun binatang.

\section{E. Perkembangan Media Pembelajaran}

Mulanya media hanya dianggap sebagai alat bantu mengajar guru (teching aids). Alat bantu yang dipakai adalah alat bantu visual, misalnya gambar, model, objek, dan alat-alat lain yang dapat memberikan pengalaman konkret, motivasi belajar serta mempertinggi daya serap dan retensi belajar siswa. Dengan masuknya pengaruh teknologi audio pada sekitar pertengahan abad ke-20, alat visual untuk mengkonkretkan ajaran ini dilengkapi dengan alat audio sehingga kita kenal adanya alat audio visual atau audio visual aids (AVA).Dalam usaha memanfaatkan media sebagai alat bantu ini Edgar Dale mengadakan klasifikasi pengalaman menurut tingkat dari yang paling konkret ke yang paling abstrak. Klasifikasi tersebut kemudian dikenal dengan nama kerucut pengalaman (cone of experience) dari Edgar Dale.

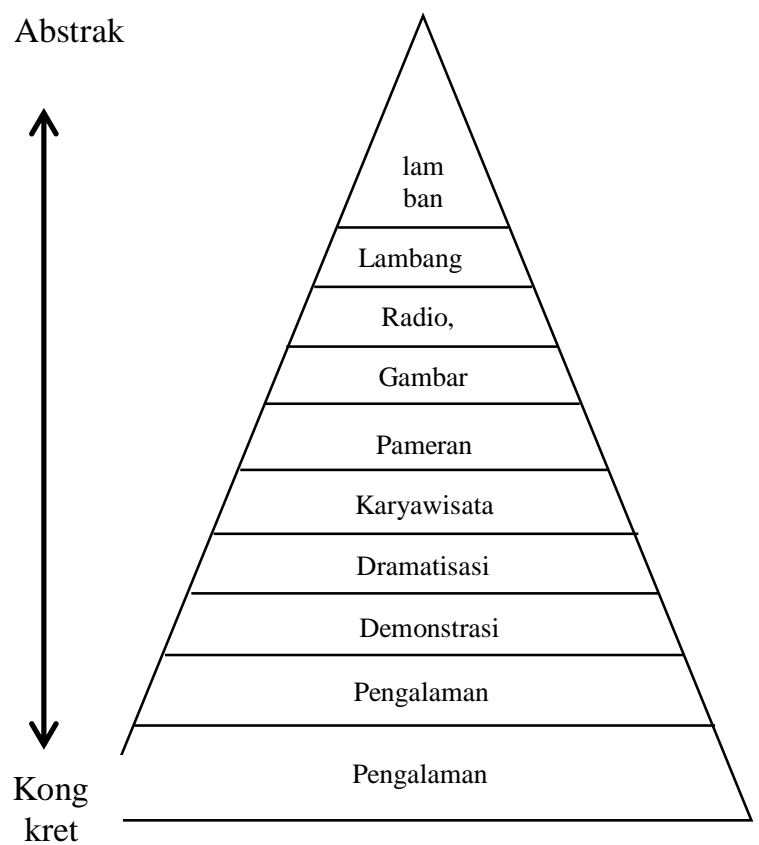

Gambar 1. Kerucut Pengalaman E. Dale

Berdasarkan kerucut pengalaman E. Dale tersebut terdapat empat jenis pengalaman belajar, yaitu: a) mengamati dan berinteraksi dengan lambang verbal, misalnya mendengarkan ceramah; b) mengamati dan berinteraksi dengan mediated 
events, misalnya menonton slide, video/VCD, film; c) mengamati dan berinteraksi dengan actual events, misalnya fildtrip, demonstration, sosiodrama (roleplay); d) melakukan dalam pengalaman langsung. Pemikiran E.Dale tentang kerucut pengalaman (Cone of experience) ini merupakan upaya awal untuk memberikan alasan atau dasar tentang keterkaitan antara teori belajar dengan komunikasi audio visual.

\section{METODE}

Sesuai dengan uraian pada latar belakang, pembatasan masalah, perumusan masalah dan tujuan penelitian yang telah dijelaskan sebelumnya maka penelitian ini digolongkan pada jenis penelitian deskriptif. Metode deskriptif dimaksud untuk melihat, meninjau dan mengetahui, serta mengungkap sesuatu apa adanya saat sekarang ini.

\section{HASIL DAN PEMBAHASAN}

\section{A. Deskripsi Hasil Penelitian}

a. Indikator Peserta

Data dari indikator peserta dapat ditampilkan yaitu sebagai berikut:

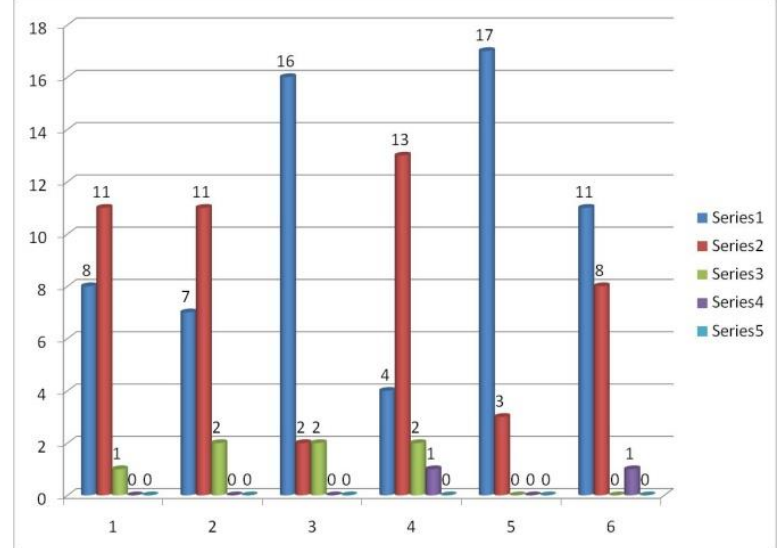

Gambar 1. Data Indikator Peserta

Dari hasil data diatas dapat dilihat pada untuk indikator peserta diperoleh rata-rata skor adalah 4,43 dengan tingkat capaian responden sebesar 88,67\% yang berarti berada dalam kategori baik.

b. Indikator Fasilitator/Pelatih

Data dari indikator Fasilitator/Pelatih dapat ditampilkan yaitu sebagai berikut:

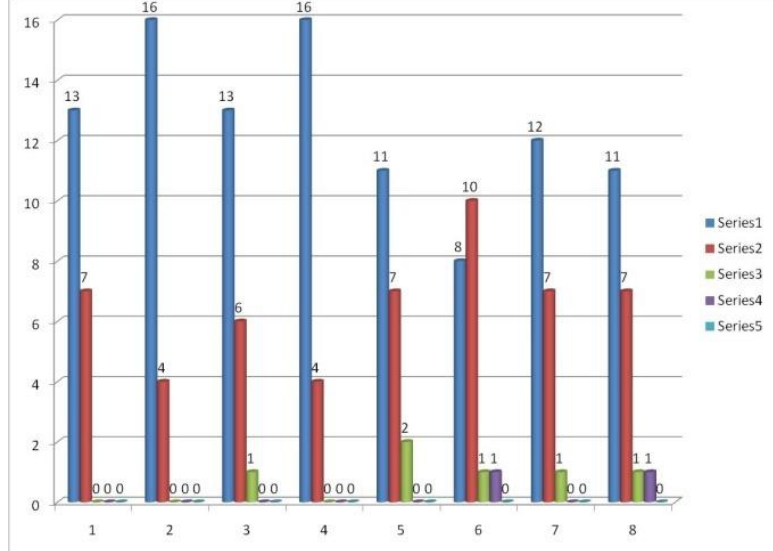

Gambar 2. Data Indikator Fasilitator/Pelatih

Dari hasil data diatas dapat dilihat pada untuk indikator fasilitator/pelatih diperoleh rata-rata skor adalah 4,56 dengan tingkat capaian responden sebesar $91,25 \%$ yang berarti berada dalam kategori sangat baik.

c. Indikator Metode

Data dari indikator metode dapat ditampilkan yaitu sebagai berikut:

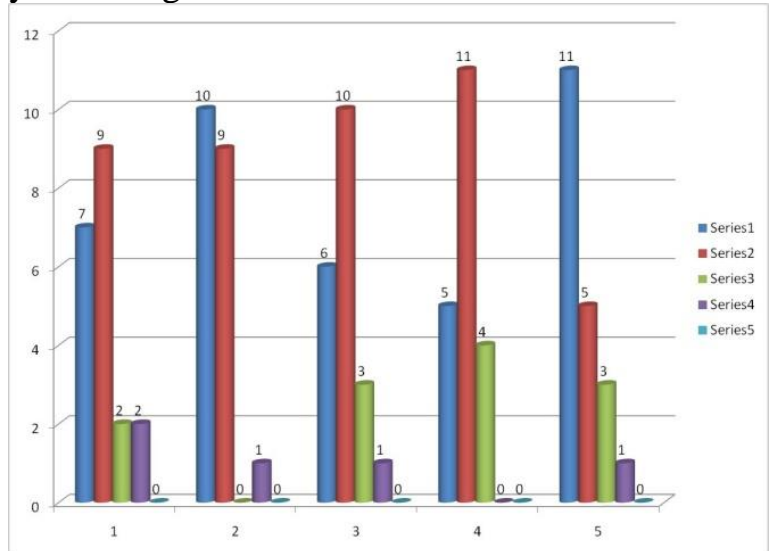

Gambar 3. Data Indikator Metode

Dari hasil data diatas dapat dilihat pada untuk indikator peserta diperoleh rata-rata skor adalah 4,17 dengan tingkat capaian responden sebesar $83,40 \%$ yang berarti berada dalam kategori baik.

d. Indikator Fasilitas dan Konsumsi

Data dari indikator fasilitas dan konsumsi dapat ditampilkan yaitu sebagai berikut: 


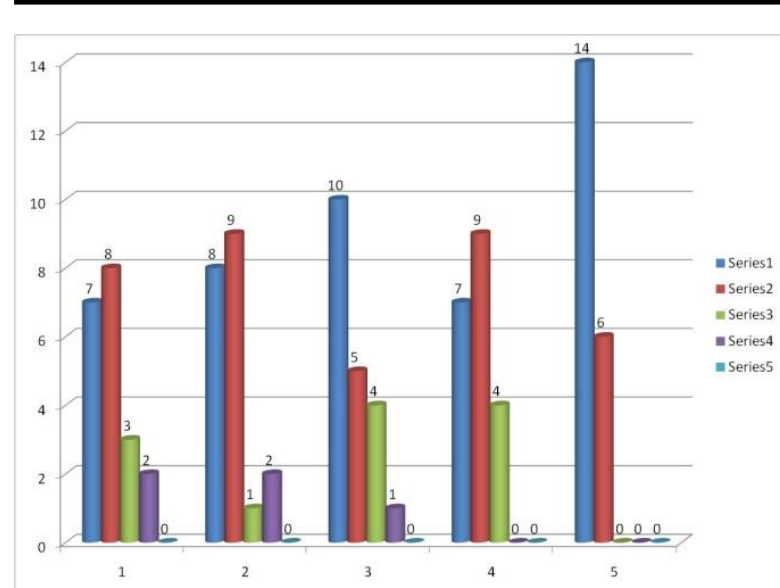

Gambar 4. Data Indikator Fasilitas dan Konsumsi

Dari hasil data diatas dapat dilihat pada untuk indikator fasilitas dan konsumsi diperoleh rata-rata skor adalah 4,42 dengan tingkat capaian responden sebesar $84,80 \%$ yang berarti berada dalam kategori baik.

\section{B. Pembahasan}

Hasil penelitian yang telah dibuktikan melalui deskripsi data akan di diskusikan dengan teori-teori dan hasil penelitian yang relevan.

Pertama, berdasarkan deskripsi variabel penelitian untuk indikator peserta, dapat diketahui bahwa tingkat capaian jawaban responden pada indikator peserta berada pada kategori baik. Hal ini terlihat dari tingkat capaian skor pada indikator ini sebesar $88,67 \%$. Pada indikator ini terdapat 6 (enam) pertanyaan yang terkait dengan peserta pelatihan.

Kedua, berdasarkan deskripsi variabel penelitian untuk indikator fasilitator dan pelatih, dapat diketahui bahwa tingkat capaian jawaban responden pada indikator fasilitator dan pelatih berada pada kategori sangat baik. Hal ini terlihat dari tingkat capaian skor pada indikator ini sebesar 91,25\%. Pada indikator ini terdapat 8 item pertanyaan yang terkait fasilitator dan pelatih.

Ketiga, berdasarkan deskripsi variabel penelitian untuk indikator metode, dapat diketahui bahwa tingkat capaian jawaban responden pada indikator metode berada pada kategori baik. Hal ini terlihat dari tingkat capaian skor pada indikator ini sebesar $83,40 \%$. Pada indikator ini terdapat 5 item pernyataan terkait dengan metode dan pelaksanaan pelatihan

Keempat, berdasarkan deskripsi variabel penelitian untuk indikator fasilitas dan konsumsi, dapat diketahui bahwa tingkat capaian jawaban responden pada indikator fasilitas dan konsumsi berada pada kategori baik. Hal ini terlihat dari tingkat capaian skor pada indikator ini sebesar $84,80 \%$. Pada indikator ini terdapat 5 item pernyataan yang terkait dengan fasilitas dan konsumsi pada saat pelatihan berlangsung.

Menurut Herman mengatakan, latihan keterampilan dapat didefinisikan sebagai suatu cara sistematik yang diberikan kepada seseorang untuk mendapatkan suatu keterampilan tertentu. Ahli lain

Wekley dan Yuke lebih terinci mengemukakan bahwa latihan dan pengembangan keterampilan adalah istilah-istilah yang menyangkut usaha-usaha berencana yang diselenggarakan agar tercapainya penuasaan keterampilan bertujuan untuk menyiapkan peserta kepada suatu pekerjaan tertentu yang berguna bagi kehidupannya.

\section{KESIMPULAN}

Adapun kesimpulan yang dapat diambil dari hasil penelitian ini adalah sebagai berikut :

a. Deskripsi variabel penelitian untuk indikator peserta, diperoleh skor rata-rata 4,43 dengan tingkat capaian responden sebesar $88,67 \%$, yang berada dalam kategori baik.

b. Deskripsi variabel penelitian untuk indikator fasilitator dan pelatih diperoleh skor rata-rata 4,56 dengan tingkat capaian responden sebesar $91,25 \%$, yang berada dalam kategori sangat baik.

c. Deskripsi variabel penelitian untuk indikator metode diperoleh skor rata-rata $4,17 \%$ dengan tingkat capaian responden sebesar 83,40 yang berada dalam kategori baik.

d. Deskripsi variabel penelitian untuk indikator fasilitas dan konsumsi diperoleh skor rata-rata $4,24 \%$ dengan tingkat capaian responden sebesar 84,80 yang berada dalam kategori baik.

\section{DAfTAR PUStaka}

[1] Priyanto Hidayatullah (2008), Making Educational Education using Flash (Membuat Animasi Pendidikan untuk Memvisualisasikan materi pelajaran), Penerbit Informatika Bandung

[2] Gintings, Abdorrakhman. 2010. Esensi Praktis Belajar dan Pembelajaran. Bandung: Humaniora

[3] Nana Sudjana. 2010. Penilaian Hasil Proses Belajar Mengajar. Bandung: PT. Remaja Rosdakarya.

[4] Susilana, Rudi dkk. 2006. Kurikulum Pembelajaran. FIP: Universitas Pendidikan Indonesia.

[5] Vaughan, Tay. 2004. Multimedia: Making It Work, Sixth Edition. McGraw-Hill Companies, Inc.

[6] Warsita, Bambang. 2008. Tekonologi Pembelajaran: Landasan \& Aplikasinya. Jakarta: RinekaCipta.

[7] Winkel, WS \& M.M Srihastuti. 2009. Bimbingan dan Konseling di Institusi Pendidikan. Yogyakarta: Media Abadi.

[8] http://www.ilmukomputer.com/uu/index.php

[9] http://www.google.com 